\title{
Mucoperiosteal Flaps with and without Removal of the Pocket Epithelium
}

\author{
Billy A. Smith, ${ }^{\star}$ Mauricio Echeverri† and Raul G. Caffesseł
}

Accepted for publication 8 April 1986

\begin{abstract}
THE PURPOSE OF THIS STUDY was to clinically evaluate the need for elimination of the pocket epithelium during mucoperiosteal flap surgery aimed at reattachment or readaptation. A split mouth design was used in 13 patients with two bicuspids and two molars included in each quadrant. Two surgical techniques were compared. One of the quadrants received a modified Widman flap with removal of the pocket epithelium, while the contralateral side received a crevicular flap without removing the pocket epithelium.

One month after the hygienic phase was completed, the following measurements were taken: Gingival Index, Plaque Index, gingival crevicular fluid flow, mobility, furcation involvement, level of attachment, pocket depth and gingival recession. In addition to these measurements, which were taken immediately prior to the surgery (baseline), 1- and 3month postsurgical measurements were also taken. Gingival recession was recorded immediately after the flaps were replaced and sutured. All data were analyzed statistically using paired $t$ test and sign test.

The biometric results showed that without the removal of the pocket epithelium, good clinical results relative to gain in clinical attachment levels and reduction in probing depth were achieved. Greater gingival recession occurred on the crevicular flap side postsurgically when compared to the modified Widman flap. The other clinical parameters remained the same at the three time intervals. This was true within each technique and when both techniques were compared.
\end{abstract}

Traditionally it has been suggested that in order to achieve reattachment, it is necessary to eliminate pocket epithelium. ${ }^{1-17}$ Many studies have been reported detailing various techniques for removal of the epithelium ${ }^{2.3 .12 .18-43}$ with several investigators having shown that complete removal of pocket epithelium as not always being an accomplished fact. ${ }^{12.21 .25-32.44-46}$ The reports vary from those who claimed that the epithelial lining could not be completely removed to those reporting consistent complete removal. ${ }^{12.17 .18 .31 .46}$ However, in spite of this incomplete removal, studies have shown that good long-term clinical results can be achieved, indicating some type of reattachment having taken place. ${ }^{47-54}$ Recent studies comparing different surgical approaches in the treatment of periodontitis, including removal of pocket epithelium versus nonsurgical approaches without removal of pocket epithelium,

* Associate Professor, Department of Periodontics, The University of Michigan School of Dentistry, Ann Arbor, MI 48109.

+ Present address: Carrera 10 No. 97-42. Bogota 8. Columbia South America.

$\ddagger$ Professor and Chairman, Department of Periodontics, The University of Michigan School of Dentistry. have shown similar results relative to pocket reduction and gain of attachment. ${ }^{55-62}$ The present study evaluated the need to eliminate pocket epithelium during mucoperiosteal flap surgery in order to establish and maintain health of the periodontal tissues.

\section{MATERIALS AND METHODS}

A total of thirteen patients, five males and eight females ranging in age from 30 to 72 years and with a median age of 40 years, were included in this study. A total of 104 teeth constituted the final sample. The subjects were selected from patients admitted to The University of Michigan School of Dentistry who were diagnosed as having moderate to advanced periodontitis and who exhibited similar bilateral bone loss and pocketing relative to two bicuspids and two molars in either the maxillary or the mandibular arch.

Following completion of the hygienic phase, the need for additional therapy was required for continuation in the study. Mucoperiosteal flaps aimed at reattachment or readaptation were indicated bilaterally as part of the proposed treatment plan. After a thorough discussion of all aspects of the study was carried out with the 
patient, he/she was asked to sign a consent form and was then given a specific time for the initial appointment.

Upon completion of hygienic phase, and at 1 month and 3 months after surgery, the following measurements and indices were taken for biometric evaluation in the sequence presented: gingival crevicular fluid flow, Plaque Index, ${ }^{63}$ Gingival Index,${ }^{64}$ pocket depth, level of attachment, gingival recession, furcation involvement ${ }^{65}$ and mobility. ${ }^{66}$

Clinical attachment levels, probing depths and amount of gingival recession were measured on two bicuspids and two molars at each of the following tooth locations: mesial buccal (MB), buccal (B), distal buccal (DB), mesial lingual (ML) and lingual (L).

All biometric measurements, except gingival recession, were taken at baseline (immediately before surgery), 1 month and 3 months after surgery. Gingival recession was measured prior to surgery (prebaseline), immediately after the flaps were replaced and sutured (baseline) and 1 and 3 months after surgery.

Using the "split-mouth" design, one side of the arch was treated with a reverse bevel incision as part of a modified Widman flap. ${ }^{59}$ The contralateral side was treated with an intracrevicular incision as part of a crevicular mucoperiosteal flap. ${ }^{51}$ The "toss of the coin" method was used to decide which quadrant would be treated by the modified Widman flap or the crevicular flap.

In compliance with the design of the study, all patients were seen at 1 and 3 months postsurgically. All clinical measurements were taken and recorded at the appropriate time interval by the same examiner following the established criteria.

The data obtained were analyzed using the Michigan Interactive Data Analysis System (MIDAS).

Analysis of the biometric measurements obtained at baseline, 1 and 3 months was carried out. The paired $t$ test and the sign test were used to compare the two surgical techniques employed at the three time intervals. Additionally, each technique was tested separately comparing baseline with 1 and 3 months.

The paired $t$ test was used for the analysis of the following clinical variables: gingival crevicular fluid flow, level of attachment, probing depth and gingival recession. Differences between the two techniques for clinical variation of Plaque Index, Gingival Index, mobility and furcation involvement were analyzed with the sign test. The difference between mean measurements within a subject at 1 and 3 months was the variable analyzed. The null hypothesis was rejected at the 0.05 level of significance.

\section{RESULTS}

Table 1 shows the difference from baseline in gingival crevicular fluid flow values at 1 and 3 months comparing both techniques with the use of the paired $t$ test. The only statistically significant difference between the two surgical techniques occurred at baseline on the buccal surfaces of the second bicuspids.

The percentage distribution of surfaces, as related to the Plaque Index for both treatments (modified Widman flap and crevicular flap) at baseline, 1 month and 3 months, are presented in Table 2 . The percentage distribution of surfaces according to the Gingival Index for both treatment modalities at baseline, 1 and 3 months are presented in Table 3. There were no significant differences between the two surgical techniques when analyzing changes in the Plaque Index and Gingival Index at the baseline, 1- and 3-month time intervals.

Table 4 shows the mean changes in probing depth measurements when comparing the modified Widman flap and crevicular flap using the paired $t$ test. Both modalities of treatment were shown to reduce pocket depth significantly at 1 and 3 months. There was a statistically significant difference interproximally at 1

Table 1

Differences from Baseline in Gingival Crevicular Fluid Flow Values Comparing the Modified Widman and Crevicular Flaps*

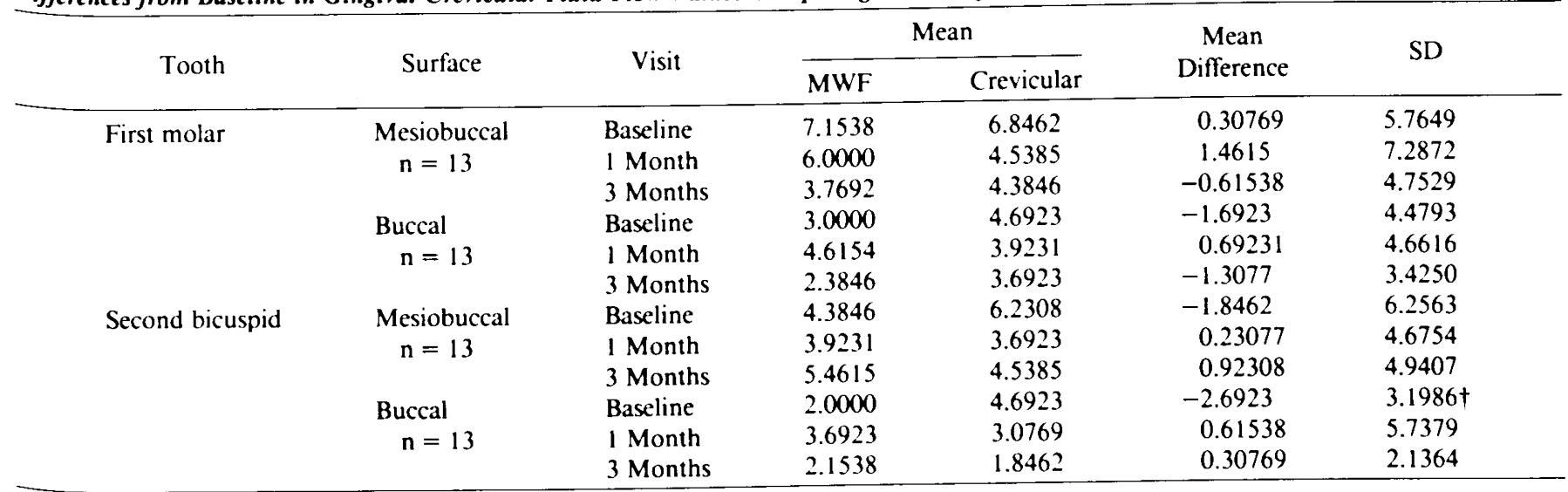

* Paired $t$ test.

$+P<0.05$. 
Table 2

Plaque Index, Frequency and Percentages of Surfaces*

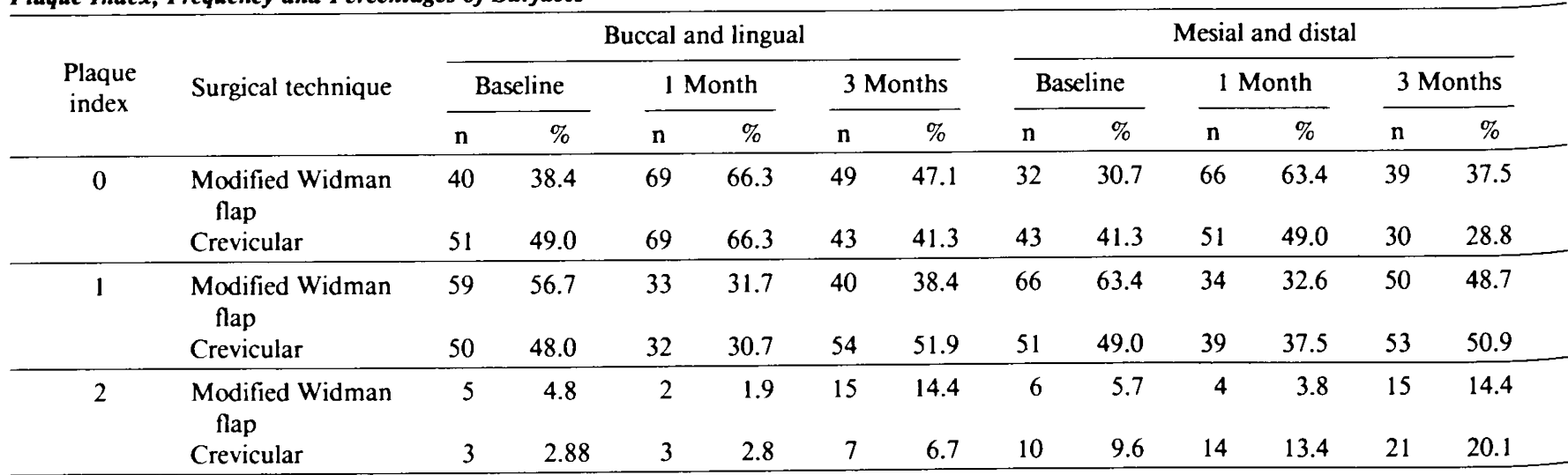

* No PII = 3 was observed.

Table 3

Gingival Index, Frequency Distribution and Percentages of Surfaces ${ }^{\star}$

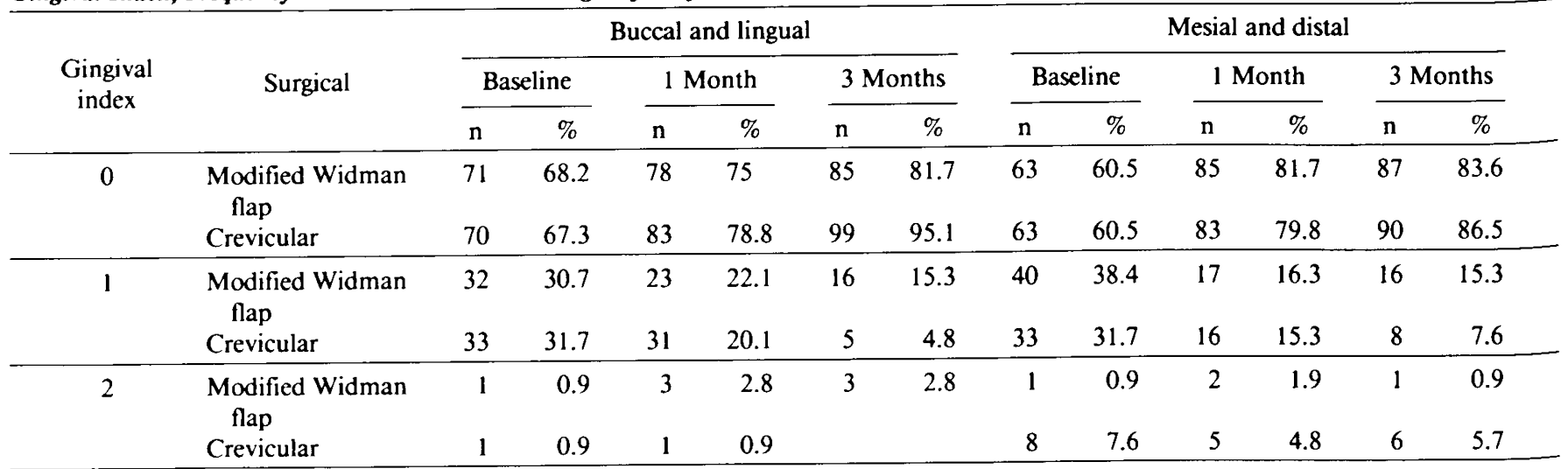

* No GI $=3$ was observed.

Table 4

Mean Changes in Probing Depth Measurements Comparing the Modified Widman (MWF) and Crevicular Flaps*

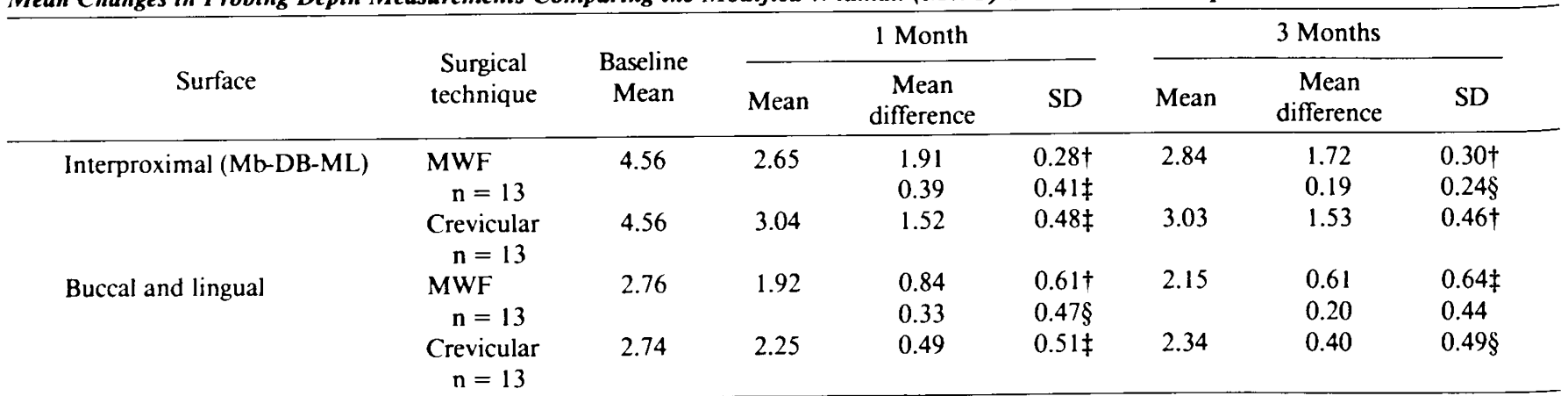

\footnotetext{
* Paired $t$ test.

$+P<0.001$.

$\ddagger P<0.01$.

$\S P<0.05$.
}

and 3 months and buccally and lingually at 1 month when the two techniques were compared.

Table 5 presents mean differences in probing depths within and between the different surgical techniques from baseline, and at 1 and 3 months. The modified Widman flap reduced probing depth significantly at 1 and 3 months regardless of initial depth. The crevicular flap reduced probing depth significantly in the $>4 \mathrm{~mm}$ group only. Significant differences between procedures were found at all levels of initial probing depths.

Table 6 shows mean changes in clinical attachment levels comparing the modified Widman and crevicular 
flap, from baseline to 1 and 3 months. Interproximally there was a statistically significant gain in clinical attachment with both surgical techniques when comparing the 1 and 3 month time intervals with baseline. There was a statistically significant loss of clinical attachment buccally and lingually with both surgical techniques when comparing 3 months with baseline. There were no significant differences between the two surgical procedures at either the 1- or 3-month time interval.
The mean changes in clinical attachment levels after performing either the modified Widman flap or crevicular flap, according to initial probing depths, are shown in Table 7. In the 1- to $3-\mathrm{mm}$ areas, there was a significant loss of attachment at the 3-month time interval for both surgical modalities and at the 1-month time interval for the crevicular flap. There were no significant differences between the two surgical techniques at either the 1- or 3-month time interval. In the $>4 \mathrm{~mm}$ areas, there were significant gains in attachment

Table 5

Mean Differences in Probing Depth from Baseline after Performing the Modified Widman (MWF) and Crevicular Flaps According to Initial Probing Depth*

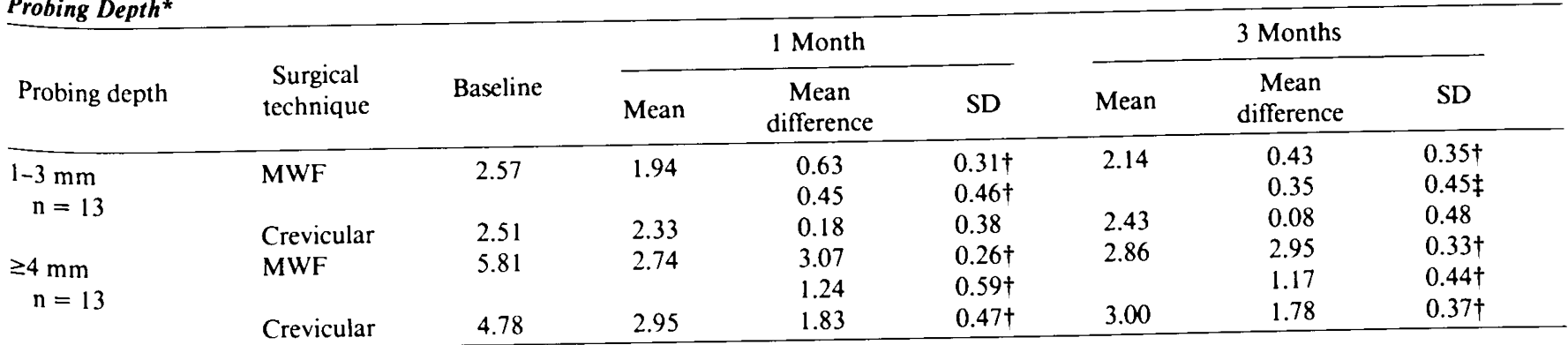

* Paired $t$ test.

$\dagger P<0.001$.

$\ddagger P<0.01$.

Table 6

Mean Changes in Clinical Attachment Levels Comparing the Modified Widman (MWF) and Crevicular Flaps

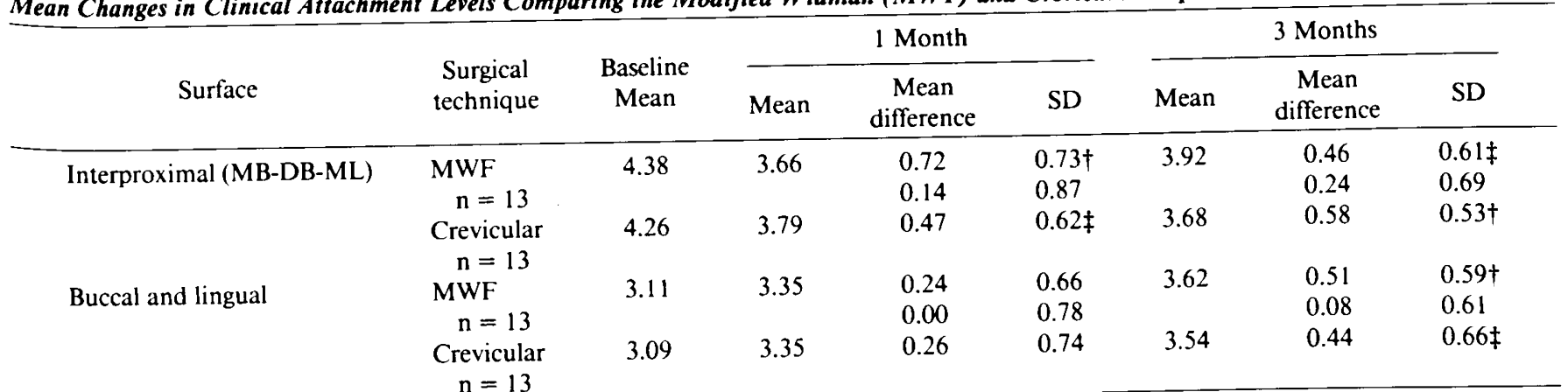

* Paired $t$ test.

$\dagger P<0.01$.

$\ddagger P<0.05$.

Table 7

Mean Differences in Clinical Attachment Levels from Baseline after Performing the Modified Widman (MWF) and Crevicular Flaps According to Initial Probing Depth*

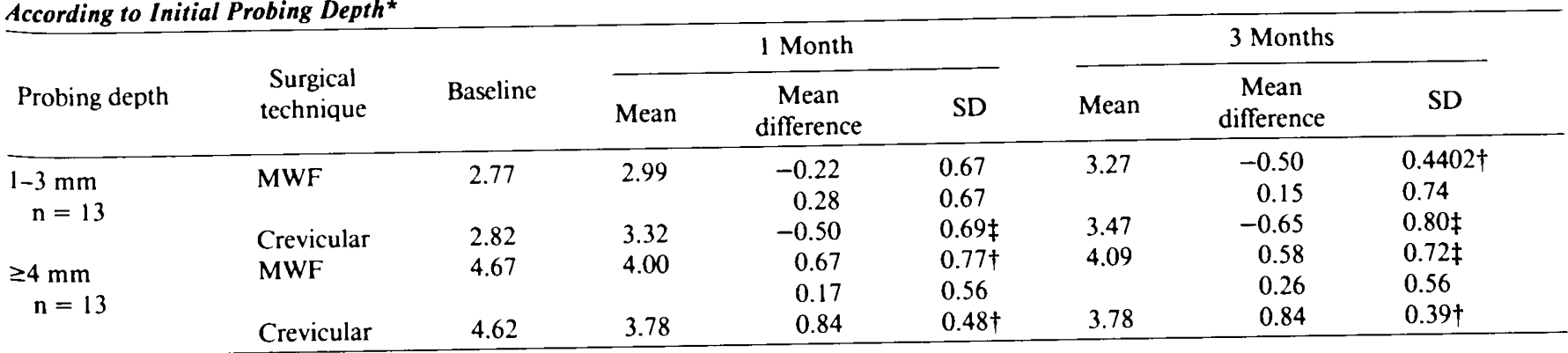

* Paired $t$ test.

$+P<0.01$.

$\ddagger P<0.05$. 
Table 8

Mean Changes in Gingival Recession* Comparing the Modified Widman (MWF) and Crevicular Flaps

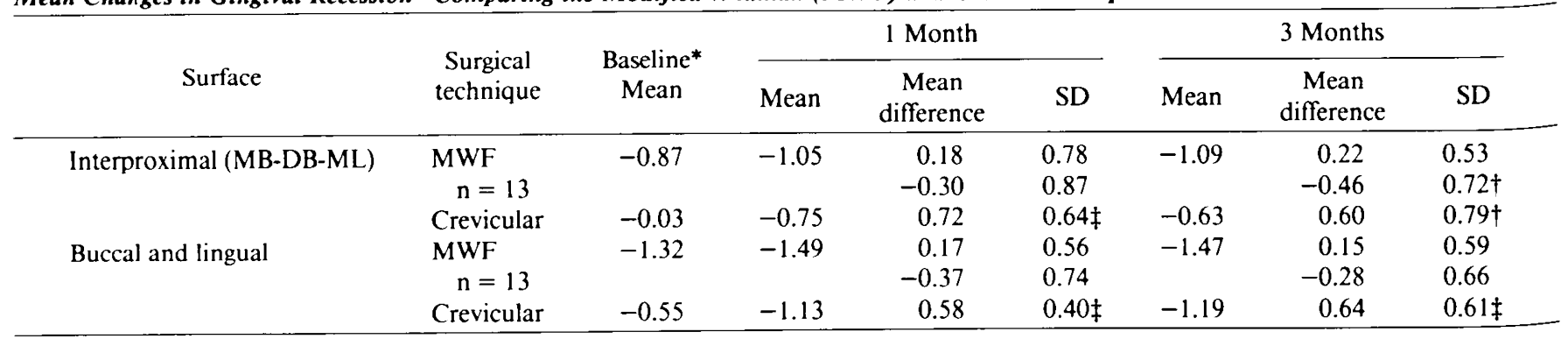

* Immediate postsurgery. Paired $t$ test

$+P<0.05$.

$\ddagger P<0.01$.

levels for both surgical techniques at the 1- and 3month time intervals. There were no significant differences between the two surgical treatments at either the 1 - or 3-month time interval.

Table 8 shows the mean changes in gingival recession comparing the two surgical methods from baseline (immediate postsurgical as measured from the CEJ to the free gingival margin after suturing) to 1 and 3 months. There were no significant changes over either time period relative to the interproximal or buccal and lingual areas after performing a modified Widman flap. There was, however, a statistically significant increase in gingival recession both interproximally and buccally and lingually at the 1- and 3-month time periods, after performing the crevicular flap. Although there was no significant difference between the two surgical treatments at 1 month for either the interproximal or buccal and lingual surfaces, there was a significant difference between the two surgical techniques at the 3-month time interval interproximally.

There were no significant changes in mobility or furcation involvement within and between the two surgical techniques according to frequency distribution analysis.

\section{DISCUSSION}

The results of this study have shown that without the removal of the pocket epithelium during flap operation, it is possible to achieve good clinical results as evaluated by clinical gain in attachment levels and reduction in probing depth. When the modified Widman and the crevicular flaps were compared at baseline and 1 and 3 months, the clinical parameters used showed comparable clinical results.

Plaque Index, Gingival Index and gingival crevicular fluid flow levels did not show any differences within the particular technique or when comparing both procedures at the different time intervals. It should be remembered that all the measurements were taken after the hygienic phase was performed. The initial low scores for these indices were, no doubt, due to this fact. An additional explanation for the low scores could also be explained by the frequent reinforcement in oral hygiene instruction, as well as the rubber cup prophylaxes received during the study. This was especially true during the first month in which the patient was seen on a weekly basis. These results are in agreement with several reports indicating that frequent professional care and adequate oral hygiene are effective in the maintenance of gingival health. ${ }^{68.69}$ No differences in gingival health were observed between the techniques. This finding is in accordance with the study by Rosling et al. ${ }^{69}$ in which different surgical treatments were used, and with professional dental cleanings, low gingival scores were observed throughout the study.

Probing depth reduction was accomplished by both techniques both interproximally and buccally and lingually. The amount of probing depth reduction achieved was statistically significant in both treatment modalities when the 3-month interval is compared with baseline. When the modified Widman flap was compared to the crevicular flap, the former resulted in a statistically significant greater pocket reduction interproximally. This difference, however, may be considered clinically insignificant. The results of this study regarding probing depth reduction are in agreement with previous studies ${ }^{59.70-72}$ in respect to the behavior of the modified Widman flap.

An interproximal gain in clinical attachment was observed with both techniques. The results obtained by Burgett et al., ${ }^{72}$ Hill et al. ${ }^{59}$ and Knowles et al. ${ }^{70.71}$ tend to support this observation. Buccally and lingually, however, a slight but statistically significant loss of clinical attachment was noticed for both techniques. This result, once again, is in agreement with previous studies. ${ }^{59.70-72}$

The majority of the pockets found buccally and lingually were shallow (1-3 mm). Whenever surgical procedures are performed in shallow crevices, loss of attachment may be expected. ${ }^{71}$

As expected, more gingival recession occurred immediately following the modified Widman flap. This was due to the reverse bevel incision performed in this technique. However, when the results at baseline (meas- 
ured after the flaps were replaced and sutured) were compared with the 3-month interval, there was a greater gingival recession when the crevicular flap was performed. The difference between the techniques was clinically insignificant. We can only speculate regarding this phenomenon. Possible explanations include "shrinkage" during the healing period or the presence of deep intrabony pockets underlying the flaps. Another possible reason could be that when the pocket epithelium was retained, the fibrin clot may not have held the flap in the desired position, and an apical displacement could have occurred.

Most of the teeth treated in the study had mobility Class 0 or 1 at baseline. One and 3 months later tooth mobility showed no changes. These results are in agreement with the study by Kerry and co-workers, ${ }^{73}$ which showed that neither the modified Widman flap nor subgingival curettage affected tooth mobility. Theoretically, the supracrestal fibers are severed during the two experimental procedures; however, if this did occur, mobility did not increase during the study.

Traditionally, it has been observed that the pocket epithelium must be eliminated if reattachment is sought. The modified Widman flap ${ }^{47}$ is a technique aimed at reattachment or readaptation. As part of the surgical procedure, a reverse bevel incision is used. This reverse bevel incision is used to eliminate the pocket epithelium and granulation tissue, leaving fresh connective tissue exposed. The results of this study have shown that from a clinical standpoint (gain in clinical attachment levels and reduction in probing depth) a crevicular flap may give good clinical results. It appears then that the removal of the pocket epithelium is not of critical importance. This study is indirectly supported by studies done by Baderstein et al. ${ }^{75}$ Hill et al., ${ }^{59}$ Lindhe et al., ${ }^{60}$ Morrison et al. ${ }^{74}$ in which, in spite of the lack of removal of the pocket epithelium after nonsurgical procedures, reduction of pocket depth and gain in attachment were accomplished.

Different studies ${ }^{28.76-81}$ have demonstrated healing by means of a long junctional epithelium after surgical procedures aimed at pocket epithelium removal were performed. One could speculate that the patients who received modified Widman surgery during the Michigan longitudinal study had this kind of healing. After 8 years, with good maintenance care, attachment levels have been maintained. ${ }^{70}$

Another source of speculation is reported by Listgarten et al. ${ }^{82}$ regarding a progressive replacement of junctional epithelium by connective tissue attachment after experimental periodontal surgery in rats. The clinical implications of this finding are unknown at the present. It has been suggested that a true connective attachment is more resistant to periodontal breakdown than a junctional epithelium. A recent report by Magnusson et al. ${ }^{83}$ indicates that, according to the findings, "the barrier function of a long junctional epithelium against plaque infection is not inferior to that provided by a dentogingival epithelium of normal length." A more recent study by Beaumont et al. ${ }^{84}$ compared the resistance of the long junctional epithelial adhesion and the naturally occurring dentogingival junction to artificially induced periodontal disease in Beagle dogs. They reported that there appeared to be no difference between the two types of attachment.

\section{CLINICAL SIGNIFICANCE}

The crevicular flap may be used when a flap for accessibility and visibility (to the root surface) is deemed necessary. The crevicular flap may heal by means of a long junctional epithelium which, it appears, can be maintained in health with adequate maintenance. One of the advantages of the crevicular flap over the modified Widman flap is that it is not as technically difficult and is thus less time consuming.

On the other hand, if connective tissue attachment is sought using adjunctive therapeutic resources, then a reverse bevel incision is indicated. This type of flap leaves connective tissue exposed, thus enhancing the potential for reattachment.

\section{CONCLUSIONS}

Within the limits of this study, the following conclusions can be made:

1. A crevicular flap that retains the pocket epithelium provides comparable clinical results to the modified Widman flap as measured by gain in clinical attachment and reduction in probing depth.

2. It is not imperative to remove pocket epithelium during flap operations for accessibility and when aiming at readaptation.

\section{Addendum:}

After this paper was submitted for publication, the article entitled "Scaling and granulation tissue removal in periodontal therapy" was published in J Clin Periodontol 12: 374-388, 1985, authored by Linde and $\mathrm{Ny}-$ man. The results of the present study support their findings.

\section{REFERENCES}

1. Younger, W. J.: Some of the latest phases in implantation and other operations. Dent Cosmos 25: 102, 1893.

2. Hecker, F.: Pyorrhea Alveolaris p 145. St. Louis, The C. V. Mosby Co., 1913.

3. McCall, J. O.: An improved method of inducing reattachment of the gingival tissues in periodontoclasia. Dent Items Interest 48: 342, 1926.

4. Rule, R. W.: Subgingival curettage. J Periodontol 9: 77, 1938.

5. Barkann, L.: A conservative surgical technic for the erradication of a pycrrhea pocket. J Am Dent Assoc 26: 61, 1939.

6. Orban, B.: Pocket elimination or reattachment? NY State Dent J 14: 227, 1948.

7. Morris, M. L.: Reattachment of periodontal tissue. A critical study. Oral Surg Oral Med Oral Pathol 2: 1194, 1949.

8. Goldman, H. M.: A rationale for the treatment of the infra- 
bony pocket: one method of treatment, subgingival curettage. $J$ Periodontol 20: 83, 1949.

9. Goldman, H. M.: Subgingival curettage. A rationale. J Periodontol 21: 223, 1950.

10. Ramfjord, S. P.: Experimental periodontal reattachment in Rhesus monkeys. J Periodontol 22: 67, 1951.

11. Ingle, J. I.: Periodontal curettement in the premaxilla. $J$ Periodontol 23: 143, 1952.

12. Morris, M. L.: The removal of the pocket and the attachment epithelium in humans. A histological study. J Periodontol 25: 7, 1954.

13. Chaikin. B.: Subgingival curettage. J Periodontol 25: 92, 1957.

14. Carranza, F. A.: A technic for reattachment. J Periodontol 25: 272, 1954.

15. Carranza, F. A., Jr.: La reinsercion y regeneracion de los tejidos del parodoncio marginal. Estado actual del tratamiento. Rev Asoc Odontol Argent 45: 92, 1957.

16. Schaffer, E. M.: The new attachment operation in subcrestal pockets. Oral Surg Oral Med Oral Pathol 11: 253, 1958.

17. Ratcliff, P.: An analysis of repair systems in periodontal therapy. Periodont Abstr 14: 57, 1966.

18. Stewart, H. T.: Partial removal of cementum and decalcification of tooth in the treatment of pyorrhea alveolaris. Dent Cosmos 41: 617, 1899.

19. Berlinger, A.: Elimination of periodontal pockets. Dent Digest 56: $397,1950$.

20. Wertheimer, F. W.: Effectiveness of "Berliner Epithelial Scalpel $^{\prime \prime}$ in removing the epithelial lining of periodontal pockets. J Periodontol 25: 264, 1954.

21. Waerhaug. J.: The gingival pocket. Odontol Tidsk (suppl.) 1, 1952.

22. Barletta, B. O., Caffesse, R. G., and Carranza, F. A., Jr.: La eliminacion del epitelio de la bolsa periodontal por medio del curetaje subgingival. Rev Asoc Odontol Argent 51: 146, 1963.

23. Moscow, B. S.: The response of the gingival sulcus to instrumentation: a histological investigation. II. Gingival curettage. J Periodontol 35: 112, 1964.

24. Blass, J. L., and Lite, T.: Gingival healing following surgical curettage. A histopathologic study. NY State Dent J 25: 127, 1959.

25. Sato, M.: Histopathological study of the healing process after surgical treatment for alveolar pyorrhea. Bull Tokyo Dent Coll 1: 71, 1960.

26. Kon, S., Novaes, A. B., Ruben, M. P., and Goldman, H. M.: Visualization of the healing periodontal wound. $J$ Periodontol 40: 96 , 1969.

27. Stahl, S. S., Weiner, J. M., Benjamin, S., and Yamada, L.: Soft tissue healing following curettage and root planing. $J$ Periodontol 42: $678,1971$.

28. Yukna. R. A.: A clinical and histologic study of healing following the excisional new attachment procedure in Rhesus monkeys. J Periodontol 47: 701, 1976.

29. Bowen, W. J., Bowers, G. M., Berquist, J. J., and Organ, R.: Removal of pocket epithelium in humans utilizing an internally beveled incision. Int J Periodont Rest Dent 1: 8, 1981.

30. Fisher, M. R., Bowers. G. M., and Bergquist, J. J.: Effectiveness of the reverse bevel incision used in the modified Widman procedure in removing pocket epithelium in humans. Int $J$ Period Rest Dent 2: 33, 1982.

31. Goldman, H. M.: Curettage by ultrasonic instruments. Preliminary report. Oral Surg Oral Med Oral Pathol 13: 43, 1960.

32. Nadler, H.: Removal of crevicular epithelium by ultrasonic curettes. J Periodontol 33: 220, 1962.

33. Miller, S. C., and Sorrin. S.: The action and the use of sodium sulphide as an epithelial solvent. Dent Cosmos 69: 113, 1927.

34. Blass, J. L.: Medical aids in conservative periodontal treatment. Dent Cosmos 73: 671. 1931.

35. Beube. F. E.: An experimental study of the use of sodium sulphide solution in the treatment of periodontal pockets. $J$ Periodontol 10: 49, 1939.
36. Rosenthal, S. L.: Conservative methods for reduction of the periodontal pocket. Dent Items Interest 72: 154, 1950.

37. Waerhaug, J., and Löe, H.: Effect of phenol camphor on gingival tissue. J Periodontol 29: 59, 1958.

38. Box, K. F.: Concerning the role of antiformin-citric acid in pocket therapy. J Ont Dent Assoc 29: 437, 1952.

39. Glickman, I., and Patur, B.: Histologic study of the effect of antiformin on the soft tissue wall of periodontal pockets in human beings. J Am Dent Assoc 51: 420, 1955.

40. Johnson, R. E., and Waerhaug, J.: Effect of antiformin on gingival tissues. J Periodontol 27: 24, 1956.

41. Tussing, G. J.: Chemical subgingival curettage. Principles and Practice of Periodontics, p 78. F. M. Wentz (eds) Springfield, Charles C Thomas, 1978.

42. Kalkwarf, K. L., Tussing, G. J., and Davis, M. J.: Histologic evaluation of gingival curettage facilitated by sodium hypochlorite solution. J Periodontol 53: 63, 1982.

43. Vieira, E. M., O'Leary, T. J., and Kafrawy, A. H.: The effect of sodium hypochlorite and citric acid solutions on healing of periodontal pockets. J Periodontol 53: 71, 1982.

44. Stone, S., Ramfjord, S. P., and Waldron, J.: Scaling and gingival curettage. A radioautographic study. $J$ Periodontol 37: 415, 1966.

45. Sanderson, A. D.: Gingival curettage by hand and ultrasonic instruments. A histological comparison. J Periodontol 37: 279, 1965.

46. Ramfjord, S. P., and Nissle, R. R.: The modified Widman flap. J Periodontol 45: 601, 1974.

47. Ramfjord, S. P.: Reattachment in periodontal therapy. J Am Dent Assoc 45: 513, 1952.

48. Ramfjord, S. P.: Present status of the modified Widman flap. J Periodontol 48: 558, 1977.

49. Smith, T. S.: The emetin hydrochlorid question in the treatment of periodontal disease (Pyorrhea alveolaris). J Am Med AssoC 64: 1567,1915

50. Leonard, H. J.: Periodontia treatment for maximum reattachment. J Am Dent Assoc 22: 602, 1935.

51. Linghorne, W. J., and O'Connell, D. C.: Studies in the reattachment and regeneration of the supporting structures of the teeth. III. Regeneration in epithelized pockets. J Dent Res 34: 164, 1955.

52. Cross, W. G.: Reattachment following curettage. Dent Pract 7: $38,1956$.

53. Linghorne, W. J.: Studies in the reattachment and regeneration of the supporting structures of the teeth. IV. Regeneration in epithelized pockets following the organization of a blood clot. $J$ Dent Res 36: 4, 1957.

54. Greco, G., and Aukhil, I.: Periodontal healing following different combinations of tissue preparations, (AADR Abstr. No. 69) $J$ Dent Res 62: 276, 1983.

55. Lang, N. P., Morrison, E. C., Löe, H., and Ramfjord, S. P.: Longitudinal therapeutic effects on the periodontal attachment level and pocket depth in Beagle dogs. I. Clinical findings. $J$ Periodont Res 14: 418, 1979.

56. Ainslie, P. T., and Caffesse, R. G.: A biometric evaluation of gingival curettage (I). Quintessence Int 5: 519, 1981.

57. Ainslie, P. T., and Caffesse, R. G.: A biometric evaluation of gingival curettage (II). Quintessence Int 6: 609, 1981.

58. Echeverria, J. J., and Caffesse, R. G.: Effects of gingival curettage when performed 1 month after root instrumentation. A biometric evaluation. J Clin Periodontol 10: 277, 1983.

59. Hill, R. W., Ramfjord, S. P., Morrison, E. C., et al.: Four types of periodontal treatment compared over two years. $J$ Periodontol 52: 655, 1981.

60. Lindhe, J., Westfelt, E., Nyman, S., et al.: Healing following surgical/non-surgical treatment of periodontal disease. A clinical study. J Clin Periodontol 9: 115, 1982.

61. Pihlstrom, B. L., Ortiz-Campos, C., and McHugh, R. B.: A randomized four-year study of periodontal therapy. J Periodontol 52: 227,1981 . 
62. Svoboda, P. J., Reeve, C. M., and Sheridan, P. J.: Effect of retention of gingival sulcular epithelium on attachment and pocket depth after periodontal surgery. $J$ Periodontol 55: 563, 1985.

63. Silness, J., and Löe, H.: Periodontal disease in pregnancy. II. Correlation between oral hygiene and periodontal condition. Acta Ondontol Scand 22: 121, 1964.

64. Löe, H., and Silness, J.: Periodontal disease in pregnancy. I. Prevalence and severity. Acta Odontol Scand 21: 533, 1963.

65. Ramfjord, S. P., and Ash, M. M.: Periodontology and Periodontics, p 666. Philadelphia, W. B. Saunders, 1979.

66. Ramfjord, S. P.: The periodontal disease index (PDI). J Periodontol 38: 602, 1967.

67. Neumann, R.: Die Alveolarpyorrhoe und ihre Behaunlung, ed 3. Berlin, Verlag von Hermann Meusser, 1920.

68. Nyman, S., Rosling, B., and Lindhe, J.: Effect of professional tooth cleaning on healing after periodontal surgery. J Clin Periodontol 2: $80,1975$.

69. Rosling. B., Nyman, S., Lindhe, J. The healing potential of periodontal tissues following different techniques of periodontal surgery in plaque-free dentitions. A two year clinical study. J Clin Periodontol 3: 233, 1976.

70. Knowles, J. W., Burgett, F. G., Nissle, R. R., et al.: Results of periodontal treatment related to pocket depth and attachment level. Eight years. J Periodontol 50: 225, 1979.

71. Knowles, J. W., Burgett, F. G., Morrison, E. C., et al.: Comparison of results following three modalities of periodontal therapy related to tooth type and initial pocket depth. J Clin Periodontol 7: $32,1980$.

72. Burgett, F. G., Knowles, J. W., Nissle, R. R., et al.: Short term results of three modalities of periodontal treatment. J Periodontol 48: 131, 1977.

73. Kerry, G. J., Morrison, E. C., Ramfjord, S. P., et al.: Effect of periodontal treatment on tooth mobility. J Periodontol 51: 635, 1982.

74. Morrison, E. C.. Ramfjord, S. P., and Hill, R. W.: Short-term effects of initial non-surgical periodontal treatment (hygienic phase). J Clin Periodontol 7: 199, 1980.

75. Baderstein, A., Nilveus, R., and Egelberg, J.: Effect of non- surgical periodontal therapy. I. Moderately advanced periodontitis. $J$ Clin Periodontol 8: 57, 1981.

76. Skillen, W. G., and Lundquist, G. R.: An experimental study of periodontal membrane reattachment in healthy and pathologic tissues. J Am Dent Assoc 24: 175, 1937.

77. Caton, J., and Zander, H.: The attachment between tooth and gingival tissues after periodic root planing and soft tissue curettage. $J$ Periodontol 50: 462, 1979.

78. Caton, J., and Nyman, S.: Histometric evaluation of periodontal surgery. I. The modified Widman flap procedure. J Clin Periodontol 7: 213, 1980.

79. Caton, J., Nyman, S., and Zander, H.: Histometric evaluation of periodontal surgery. II. Connective tissue attachment levels after four regenerative procedures. J Clin Periodontol 7: 224, 1980.

80. Stahl, S. S., Froum, S. J., and Kishner, L.: Periodontal healing following open debridement flap procedures. Il. Histologic observations. J Periodontol 53: 15, 1982.

81. Nyman, S., Lindhe, J., and Karring, T.: Healing following surgical treatment and root demineralization in monkeys with periodontal disease. J Clin Periodontol 88: 249, 1981.

82. Listgarten, M. A., Rosenberg, S., and Lerner, S.: Progress replacement of epithelial attachment by a connective tissue junction after experimental periodontal surgery in rats. $J$ Periodontol 53: 659, 1982.

83. Magnusson, I., Runstad, L., Nyman, S., and Lindhe, J.: A long junctional epithelium - a locus minoris resistentiae in plaque infection. J Clin Periodontol 10: 333, 1983.

84. Beaumont, R. H., O'Leary, T. J., and Kafrawy, A. H.: Relative resistance of long junctional epithelial adhesions and connective tissue attachments to plaque-induced inflammation. J Periodontol 55: 213, 1984.

Send reprint requests to: Dr. Billy A. Smith. The University of Michigan, School of Dentistry, Department of Periodontics, Ann Arbor, MI 48109.

\section{Announcement}

\section{EASTMAN DENTAL CENTER}

The Eastman Dental Center announces the following course:

TithE: The Periodontal Lesion: Diagnosis and Management

DATES: Thursday and Friday, April 30-May 1, 1987

Location: Eastman Dental Center

625 Elmwood Avenue

Rochester, NY 14620

FACULTY: Alan M. Polson, DDS, MS

Jack G. Caton, DDS, MS

The course addresses current concepts of etiology, diagnosis and treatment of the periodontal lesion. Research findings will be integrated into a rational approach for patient management. Topics include natural history of periodontitis, disease activity, trauma from occlusion in pathogenesis and management of disease, nonsurgical vs. surgical therapy and periodontal regeneration.

For more information contact: Jo Helfer, Eastman Dental Center, 625 Elmwood Ave, Rochester, NY 14620. (716) 275-5064 